ACTA UNIVERSITATIS WRATISLAVIENSIS

PRZEGLĄD PRAWA I ADMINISTRACJI CXX/2

WROCŁAW 2020

https://doi.org/10.19195/0137-1134.120.67

\author{
SYLWIA SKUBISZ-ŚLUSARCZYK \\ ORCID: 0000-0003-1172-8286 \\ Uniwersytet Wrocławski \\ Katedra Kryminalistyki
}

\title{
O POMYŁCE SĄDOWEJ W KONTEKŚCIE WIEDZY KRYMINALISTYCZNEJ
}

\begin{abstract}
Abstrakt: Pomyłki sądowe zdarzały się w przeszłości, zdarzają się obecnie i zapewne będą mieć miejsce w przyszłości. Sygnały dotyczące ich występowania pojawiały się w literaturze. Aktualnie również są przedmiotem rozważań, nie tylko na gruncie naukowym, lecz także medialnym. Analizując problem oraz spoglądając na niego z perspektywy czasu, można zaryzykować stwierdzenie, że pomyłki sądowe służyły postępowi, przełamując pewne schematy i bariery, prowadząc jednocześnie do rozwoju kryminalistyki i procedury karnej. Wśród wielu pytań (co jest powodem pomyłek sądowych), jakie nasuwają się po lekturze badań, analiz, ankiet, pojawia się kolejne, dotyczące wymiaru wiedzy kryminalistycznej przekazywanej na polskich uczelniach. Pytanie to przekłada się na kolejne, odnoszące się do poziomu wiedzy kryminalistycznej bądź jej braku w pracy organów wymiaru sprawiedliwości. Taki stan generuje kolejne tezy, które nawiązują do nielicznych podnoszonych głosów dotyczących stanu kształcenia na poziomie studiów prawniczych. W związku z tym podjęte zostały działania mające na celu zestawienie danych odnoszących się do ilości i jakości (formy) zajęć prowadzonych z przedmiotu kryminalistyka na polskich uczelniach oraz aplikacjach prawniczych.
\end{abstract}

Słowa kluczowe: pomyłka sądowa, niesłuszne skazania, wiedza kryminalistyczna

W literaturze na przestrzeni lat pojawiło się wiele schematów metodologicznych dotyczących omawianego zagadnienia pomyłek sądowych. Prowadzone były różne badania w mniej lub bardziej zaawansowanej formie. Obejmowały one wielopłaszczyznowe analizy, odnoszące się między innymi do: liczby przypadków niesłusznych skazań, ich skutków, diagnozy przyczyn niesłusznych skazań, spraw, w których doszło do naruszenia prawa ${ }^{1}$.

Skąd bierze się wskazany stan rzeczy — z jakiego powodu dochodzi do pomyłki? To pytanie niejednokrotnie było zadawane i zapewne zostanie ponowione. Nawiązując do naukowych podstaw, niech odpowiedź na nie, która jest niewątpliwie wielowątkowa, będzie jednocześnie bardzo przewrotna. Skoro dzięki postę-

1 O. Mazur, Niestuszne skazania w Polsce $w$ opinii prokuratorów i policjantów, „Palestra” 2012, nr 3-4, s. 21.

Przegląd Prawa i Administracji CXX, 2020, cz. 1 i 2

(C) for this edition by CNS 
pom w kryminalistyce udało się doprowadzić do uniewinnienia wielu skazanych, między innymi w Stanach Zjednoczonych ${ }^{2}$, to należy postarać się, aby dzięki kryminalistyce $\mathrm{w}$ przyszłości doszło do eliminowania pomyłek sądowych, biorąc pod rozwagę kolejne etapy prowadzonego postępowania przygotowawczego i nie tylko. Mając na uwadze wnioski wynikające z przeprowadzonych dotychczas badań, które zostaną pokrótce zaprezentowane, warto zwrócić uwagę na aspekt odpowiedniego przygotowania przyszłych sędziów, prokuratorów czy adwokatów w zakresie wiedzy kryminalistycznej.

Na wstępie należy przytoczyć ogólne znaczenie samego terminu ,pomyłka”. Zgodnie ze słownikiem języka polskiego oznacza ona „spostrzeżenie, sąd niezgodny z rzeczywistością, niewłaściwe postępowanie, posunięcie"3. Przeniesienie tego sposobu rozumowania na grunt prawny nakazywałoby uznawać za pomyłkę sądową każdy błąd sądu, który zostanie stwierdzony w postępowaniu odwoławczym. Jednak takie podejście jest niewłaściwe, ponieważ w żaden sposób nie precyzuje opisywanego problemu ${ }^{4}$. Dlatego w piśmiennictwie podejmuje się próby stworzenia bardziej przejrzystej definicji.

Pomyłkę sądową utożsamia się zazwyczaj z niesłusznym skazaniem i odnosi się ją do orzeczeń sądowych, na mocy których skazano niewinną osobę, a następnie zastosowano nadzwyczajne środki odwoławcze, takie jak wznowienie postępowania w związku z pojawieniem się nowych dowodów sądowych bądź kasację ${ }^{5}$.

W literaturze proponuje się również nieco szersze pojmowanie pomyłki sądowej, rozumianej jako wadliwe orzeczenie sądowe, które zawiera „mylne mniemanie (niezgodne z rzeczywistym stanem rzeczy), że dana osoba jest sprawcą czynu lub że nie jest sprawcą — mimo że w rzeczywistości było inaczej”6. W tym ujęciu pomyłki sądowe obejmują dwie sytuacje: prawomocne niesłuszne skazania oraz prawomocne niesłuszne uniewinnienia ${ }^{7}$.

Problem pomyłek sądowych był już sygnalizowany i opisywany w latach sześćdziesiątych XX wieku ${ }^{8}$ w kontekście odszkodowań za niesłuszne skazanie i bezzasadny areszt. Do 2007 roku, kiedy to pojawiła się praca prezentująca kom-

2 A. Kręcik, Wolność dzięki DNA, „Przegląd” 2007, nr 50, ttps://www.tygodnikprzeglad.pl/ wolnosc-dzieki-dna/ (dostęp: 23.06.2019).

3 https://sjp.pwn.pl/sjp/pomylka;2504418.html (dostęp: 28.05.2019).

4 W. Juchacz, Pomytki sadowe w sprawach o zabójstwa. Studium karno-procesowe, Bydgoszcz 2016, s.16.

5 A. Sowa, Przyczyny pomyłek sadowych, „Palestra” 2002, nr 1, s. 139; J. Widacki, A. Dudzińska, Pomytki sądowe. Skazania osób niewinnych przez sądy w Polsce, „Palestra” 2007, nr 11-12, s. 64; J. Skorupka, Pomytki sadowe w orzecznictwie Sąu Najwyższego i sądów apelacyjnych, [w:] Nieshuszne skazania - przyczyny i skutki, red. Ł. Chojniak, Warszawa 2017, s. 29.

6 W. Juchacz, op. cit., s. 16-17.

7 Ibidem, s. 16-17.

8 J. Waszczykowski, Odszkodowanie za niestuszne skazanie i bezzasadne aresztowanie w polskim procesie karnym, Łódź 1964; A. Bulsiewicz, Proces o odszkodowanie za niestuszne skazanie lub oczywiście bezzasadny areszt tymczasowy, Torun 1968. 
pleksowo omawianą materię ${ }^{9}$, publikowane były opracowania traktujące zagadnienie zawsze wycinkowo, pobieżnie. Ta opisywana diagnoza skutków niesłusznych skazań nie opierała się jednak na empirycznych badaniach, które wskazywałyby na dolegliwości różnorodnej natury, z jakimi muszą się zmagać niesłusznie skaza$\mathrm{ni}^{10}$. A przecież najistotniejsza z punktu widzenia pomyłek sądowych jest diagnoza ich przyczyn. Tej kwestii poświęconych zostało wiele opracowań, nad którymi należy się pochylić i pokrótce przedstawić wnioski ${ }^{11}$.

W 2002 roku A. Sowa ${ }^{12}$, publikując materiał odnoszący się do niesłusznych skazań, dostrzegła wagę problemu dotyczącego nie tylko polskiego wymiaru sprawiedliwości. Autorka przez odwołanie do badań empirycznych prowadzonych w krajach systemu common law zaznacza, że są one pewnego rodzaju asumptem do przeprowadzenia badań także w Polsce. Dwa rodzaje dowodów, fałszywe przyznanie się do winy i mylne rozpoznanie przez świadka to detale, które mogą prowadzić do niesłusznego skazania. Wspierając się materiałem pochodzącym z rozważań amerykańskich, Sowa zapowiadała przygotowanie kompleksowego materiału poświęconego pomyłkom sądowym w Polsce ${ }^{13}$.

W 2007 roku opublikowane zostały wyniki badań zmierzające do ustalenia przyczyn niesłusznych skazań. W analizie J. Widackiego i A. Dudzińskiej ${ }^{14}$ konkluzja jest następująca - standardy dowodzenia winy są przerażające. Według autorów badania (ankieta przeprowadzona wśród adwokatów) najczęstszym powodem skazań niewinnych jest błędne rozpoznanie w czasie okazania oraz obciążenie przez świadka koronnego lub incognito, a także przyznanie się do niepopełnionego przestępstwa. Autorzy zdają sobie sprawę, że wskazane przyczyny nie wyczerpują katalogu potencjalnych powodów występowania pomyłek sądowych ${ }^{15}$.

Kolejna próba rozpoznania zjawiska niesłusznych skazań podjęta została przez O. Mazur ${ }^{16}$ i dotyczyła odmiennej grupy zawodowej niż przyjęta przez J. Widackiego i A. Dudzińską. Uwagi O. Mazur po przeprowadzonych badaniach ankietowych wśród prokuratorów z prokuratur rejonowych oraz policjantów są następujące: nie są znane rzeczywiste dane odnoszące się do liczby osób niesłusz-

9 P. Cioch, Odpowiedzialność Skarbu Państwa z tytułu niestusznego skazania, Warszawa 2007. Praca obejmuje cywilistyczny aspekt niesłusznego skazania.

10 Zestawienie przeprowadzonych badań empirycznych z orzecznictwem dotyczącym i zasądzającym rekompensaty za niesłuszne skazanie dałoby pełną odpowiedź na pytania odnoszące się do skutków niesłusznych skazań. Ł. Chojniak, Ł. Wiśniewski, Przyczyny niesłusznych skazań w Polsce, Warszawa 2012, s. 6.

11 Przeprowadzone badania empiryczne i badania aktowe to główne wyznaczniki omawianych wyników.

12 A. Sowa, op. cit., s. 138 n.

13 Praca zapowiadana przez autorkę nie została dotychczas opublikowana.

14 J. Widacki, A. Dudzińska, op. cit., s. 64 n.

$15 \mathrm{~W}$ stosunku do przedstawionych wyników badań podniesione zostały zastrzeżenia, zob.

Ł. Chojniak, Ł. Wiśniewski, op. cit., s. 6.

16 O. Mazur, op. cit., s. 19 n.

Przegląd Prawa i Administracji CXX, 2020, cz. 1 i 2

(C) for this edition by CNS 
nie skazanych, skala zjawiska jest trudna do ustalenia, natomiast źródła niesłusznych skazań to przede wszystkim błędna identyfikacja, fałszywe samooskarżenia, jednotorowe prowadzenie postępowania, błędy w ekspertyzach, błędy oskarżenia, obrony i sądu. Jest to repertuar bardzo bogaty i złożony, dający asumpt do daleko idących przemyśleń, zwłaszcza w przypadku prokuratorów.

Próba diagnozy omawianego zjawiska była też przedmiotem koncypowania zespołu badaczy Krakowskiej Akademii im. Andrzeja Frycza Modrzewskiego ${ }^{17}$. Wnioski nie są jednoznaczne, gdyż wynikają jedynie z wypełnionego kwestionariusza skierowanego do przedstawicieli adwokatury, co pozwoliło w zasadzie jedynie na poznanie opinii ankietowanych na temat odbioru zjawiska niesłusznych skazań przez przedstawicieli różnych grup zawodowych związanych z szeroko pojętym wymiarem sprawiedliwości.

Warto w tym miejscu przedstawić również konkluzje wynikające z percepcji omawianego zagadnienia przez przeprowadzone badania aktowe. Należy uwzględnić obszerne wnioski i postulaty oraz rekomendacje zebrane po badaniach aktowych przeprowadzonych przez $Ł$. Chojniaka i Ł. Wiśniewskiego ${ }^{18}$. Niesłuszne skazania to problem, który nie ma tylko jednej przyczyny, jednego źródła. Jest to kwestia złożona $\mathrm{z}$ wielu nieprawidłowości, dysfunkcji towarzyszących rozpoznawaniu spraw karnych; żadnej z nich nie można bagatelizować. Wskazanymi w badaniach przyczynami niesłusznych skazań są między innymi:

- mankamenty prawa dowodowego, które łączą się z niepewnością samych środków dowodowych; niem;

— przyczyny wznowień postępowań zakończonych prawomocnym skaza-

- absurdy postępowań;

- uchybienia organów prowadzących postępowania;

— nieodpowiednie przygotowanie organów do orzekania;

— niedoskonały system dokształcania organów prowadzących postępowanie.

Mając na uwadze kontekst przedstawionych, uwag można wysunąć konkluzję, że niesłuszne skazania nie są spowodowane tylko nierzetelnie przeprowadzonym postępowaniem dowodowym, które prowadzi do mylnych wniosków, lecz także nieuwaga, zawinienie, niekompetencja człowieka (sędziego, prokuratora, obrońcy) może być, a niekiedy nawet jest, przyczyną pomyłki sądowej ${ }^{19}$.

Szerokie spojrzenie na zagadnienie pomyłek sądowych prezentuje W. Juchacz ${ }^{20}$, który przez pryzmat spraw o zabójstwo dokonuje ustaleń i wskazań, co jest powodem pomyłek sądowych. Wzięcie pod uwagę badań podjętych na podstawie akt spraw karnych z art. 148 kodeksu karnego pozwala wysnuć wnioski

17 Ł. Chojniak, Ł. Wiśniewski, op. cit., s. 7. Zespół badaczy nie został wskazany personalnie.

18 Raport z badań empirycznych niesłusznych skazań w Polsce. Zob. ibidem, s. 29 n.

19 Ibidem, s. 73-76.

20 W. Juchacz, op. cit.; idem, Okoliczności sprzyjające pomyłkom sq̨dowym w zakresie ustaleń faktycznych, „Prokuratura i Prawo” 2004, nr 5, s. 145-147. 
natury ogólnej, ale można także sformułować kilka bardziej szczegółowych uwag. Istotną kwestią, którą należy potraktować bardziej szczegółowo, są kwalifikacje osób prowadzących postępowania przygotowawcze i sądowe. Systematyczne szkolenia, sukcesywne podnoszenie umiejętności, w szczególności w zakresie postępowania dowodowego, to niezwykle ważne elementy, które można potraktować jako postulaty de lege ferenda.

Wskazując na przedstawione już badania, ujmujące percepcję zjawiska niesłusznych skazań w różnych konfiguracjach badawczych, nie można zignorować programu „Niewinność” Kliniki Prawa, działającego w ramach Helsińskiej Fundacji Praw Człowieka ${ }^{21}$. Klinika podejmuje działania przede wszystkim interwencyjne, związane z bieżącymi sprawami rozpoznawanymi przez sądy, oraz tymi, które prawomocnie zostały osądzone. Praca tej instytucji jest oparta na dogłębnej analizie spraw, w których mogło dojść do pomyłki sądowej lub bezpodstawnego oskarżenia. Jest to kolejny sposób na zasygnalizowanie przyczyn pomyłek sądowych, do których należą: fałszywe zeznania świadków, nieprofesjonalnie prowadzone śledztwo, błędne rozpoznanie sprawcy przez świadka, fałszywe przyznanie się do winy, naruszenie zasady in dubio pro reo ${ }^{22}$. Działalność programu „Niewinność" można skonstatować jako próbę zinstytucjonalizowanego ujęcia kwestii niesłusznych oskarżeń oraz niesłusznych skazań23.

Podsumowując omówiony wątek badawczy, można odnieść wrażenie, że istnieje spora liczba przyczyn, które można utożsamiać z podstawami pomyłek sądowych. Mogą być one różnie klasyfikowane, a ich merytoryczny obraz staje się przyczynkiem do dyskusji. Oczywiście można poszukiwać, analizować, rozważać, dlaczego taki stan rzeczy może zaistnieć, a uniknięcie pomyłek sądowych nie jest możliwe. Szukając odpowiedzi na stawiane pytania, niektórzy autorzy akcentują coś niepodważalnego i oczywistego jednocześnie — wiedzę i doświadczenie.

Stosowna wiedza to atrybut niezawisłości sędziowskiej, przedmiot ciągłej analizy dokonywanej przez prokuratora i zasób wykorzystywany w dowodzeniu niewinności przez obrońcę. Świadome jej wykorzystywanie przekłada się na jakość prowadzonych postępowań, pozwala na wybór optymalnej taktyki prowadzenia czynności procesowych, prawidłowe budowanie wersji zdarzenia czy świadome

21 http://www.hfhr.pl/klinika-niewinnosc-nowa-edycja/ (dostęp: 23.06.2019).

22 Helsińska Fundacja Praw Człowieka, Klinika Prawa „Niewinnośc”, Warszawa 2007. Broszura opublikowana przez Fundację analizuje przyczyny niesłusznych skazań, które zostały wsparte przykładami wybranych spraw sądowych, jednak nie towarzyszyły im badania empiryczne. W 2010 roku Helsińska Fundacja Praw Człowieka oraz Katedra Kryminalistyki Wydziału Prawa i Administracji Uniwersytetu Warszawskiego zorganizowały konferencję naukową poświęconą pomyłkom sądowym w postępowaniu karnym. Klinika Prawa „Niewinność” realizuje program zajmujący się wyszukiwaniem błędów popełnionych na którymś z etapów postępowania karnego, które mogły stać się przyczyną niesłusznego skazania. Program działa w ramach Helsińskiej Fundacji Praw Człowieka od 1999 roku.

23 Ł. Chojniak, Ł. Wiśniewski, op. cit., s. 8. 
i pełne korzystanie z pomocy biegłych ${ }^{24} \mathrm{w}$ wyjaśnianiu okoliczności istotnych dla rozstrzygnięcia sprawy. Odpowiednia wiedza i doświadczenie sprawiają, że wieloetapowa działalność osób prowadzących postępowania i uczestniczących w nich jest wolna od pomyłek. Czy to stwierdzenie brzmi jak truizm, okazjonalnie powtarzany banał? Operując powyższymi sformułowaniami, można stwierdzić, że mamy do czynienia z banałem, sloganem, który musi być głośno wyartykułowany, ponieważ wiedza jest niepodważalnym i niezastępowalnym elementem, niezbędnym do wykonywania zawodu prawnika. Sięgając do genealogii wiedzy prawniczej, można posłużyć się słowami E. Locarda: „sędzia będzie musiał nabrać zdolności rozumienia, zastosowania metod technicznych i oceny ich wyników"25.

Wiedza w ogólnym sensie jest rezultatem wszelkich możliwych aktów poznania, a w węższym znaczeniu — ogółem wiarygodnych informacji o rzeczywistości wraz z umiejętnością ich wykorzystania. Wiedza to ogół wiadomości zdobytych dzięki badaniom, uczeniu się, to zasób informacji z jakiejś dziedziny ${ }^{26}$. Należy skoncentrować się na źródle wiadomości z konkretnej płaszczyzny, jaką jest kryminalistyka. Problem niezbędności wiedzy kryminalistycznej prawników podnoszony był i jest zarówno w podręcznikach ${ }^{27}$, jak i na różnego rodzaju spotkaniach, sympozjach, konferencjach naukowych ${ }^{28}$. Obecne szybkie tempo życia, utechnicznienie bytu, a także skala przestępczości, stopień zagrożeń, brutalność sprawców i nowe metody popełniania przestępstw sprawiają, że kryminalistyka staje się nieocenioną i wszechobecną nauką. Wszyscy w zasadzie się z tym zgadzają, a jednak mury uczelni opuszczają prawnicy niemający holistycznej wiedzy kryminalistycznej29.

Dokonując oceny stanu wiedzy kryminalistycznej, należy zwrócić uwagę nie na pełny konglomerat przedmiotów proponowanych i wykładanych na studiach prawniczych, lecz skupić się na tej wiedzy, która z racji przyczyn pomyłek sądowych jest niezwykle istotna. Warto odpowiedzieć na pytanie, jak prezentują się zasoby wiedzy kryminalistycznej na kierunku prawo na polskich uczelniach. Liczba uczelni wyższych jest imponująca, biorąc pod uwagę uczelnie państwowe oraz prywatne. Dlatego też istniała możliwość zaznajomienia się z warstwą edukacyjną

24 Taka potrzeba postulowana jest na łamach publikacji naukowych, a wyrażał ją chociażby J. Sehn. Por. idem, Sytuacja kryminalistyki, „Palestra” 5, 1961, nr 3 (39), s. 8-12, https://www.ies. gov.pl/index.php/pl/features/parameters/104-historia/221-jan-sehn (dostęp: 27.05.2019).

25 E. Locard, Dochodzenie przestępstw wedlug metod naukowych, Łódź 1937, s. 18 n.

${ }^{26}$ https://encyklopedia.pwn.pl/szukaj/wiedza.html (dostęp: 22.06.2019).

27 Zob. m.in. E. Gruza, M. Goc, J. Moszczyński, Kryminalistyka, czyli rzecz o metodach śledczych, Warszawa 2008, s. 21 n.; M. Kulicki, V. Kwiatkowska-Wójcikiewicz, L. Stępka, Kryminalistyka. Wybrane zagadnienia teorii i praktyki śledczo-sądowej, Toruń 2009, s. 8 n.

${ }^{28}$ H. Kołecki, Zakres i sposób uprawiania kryminalistyki w Polsce, [w:] Księga pamiątkowa dedykowana Profesorowi Mirosławowi Owocowi, red. H. Kołecki, Poznań 2008, s. 397-418.

29 J. Kasprzak, Bład w jednej sprawie, czyli jeszcze raz o potrzebie znajomości kryminalistyki przez prawników, [w:] Kryminalistyka dla prawa, prawo dla kryminalistyki, red. V. Kwiatkowska-Wójcikiewicz, Torun 2010, s. 212-213. 
na podstawie danych i materiałów zamieszczonych na stronach internetowych poszczególnych uczelni ${ }^{30}$.

Mając na uwadze trzydzieści dwie uczelnie wyższe ${ }^{31}$, wyciągnięto wnioski o charakterze informacyjnym, które pokazują pewne tendencje w kształceniu polskich studentów w zakresie kryminalistyki, która znajduje się w ofercie dydaktycznej wszystkich uczelni publicznych, natomiast tylko sporadycznie pojawia się wśród przedmiotów uczelni prywatnych. W związku z tym nie wszyscy studenci prawa zaliczają ten przedmiot $\mathrm{w}$ ramach toku studiów. Na niewielu uczelniach kryminalistyka jest przedmiotem obowiązkowym kierunkowym lub specjalizacyjnym. Na większości polskich uczelni studenci wybierają ją w ramach realizowanej specjalizacji, przy czym nie zawsze kurs ten jest uruchamiany, gdyż zależy to od liczby zadeklarowanych słuchaczy. Najpopularniejsza forma prowadzenia zajęć to wykład i ćwiczenia, rzadziej kryminalistka jest realizowana jedynie w formie wykładu czy konwersatorium. Uczelnie niepubliczne realizują wskazany przedmiot wyłącznie jako wykład, sporadycznie zdarzają się ćwiczenia lub konwersatoria ${ }^{32}$. Należy dodać, że ramowy plan studiów nie pozwala na wybór odpowiedniej formy zajęć, ponieważ jest ona niejako narzucona umiejscowieniem przedmiotu w grupie innych zajęć, czy to kierunkowych, czy też zajęć do wyboru. $Z$ tej również przyczyny rozmaicie kształtuje się wymiar czasowy, w którego obrębie realizowana jest kryminalistyka. Najczęstszym przedziałem godzinowym jest zestawienie 30-45 godzin lub do 30 godzin na uczelniach prywatnych ${ }^{33}$. Oprócz klasycznej kryminalistyki niektóre uczelnie proponują także przedmioty okołokryminalistyczne, poruszające wąski wycinek tej nauki. Taka opcja jest realizowana na większości uczelni publicznych, natomiast na uczelniach niepublicznych jest to sytuacja niezwykle rzadka, a oferta bardzo skromna. Dodatkowy materiał jest realizowany w ramach przedmiotów specjalnościowych do wyboru. Kryminalistyka jako nauka interdyscyplinarna nie jest łatwym przedmiotem do realizacji, ponieważ wymaga wiedzy z różnorodnych dyscyplin naukowych i odpowiedniej kadry dydaktycznej. Z pewnym niepokojem można zaobserwować stałą tendencję do ograniczania liczby godzin zajęć z kryminalistki i traktowanie jej jako przedmiotu nieco niższej rangi, niekoniecznie potrzebnego prawnikowi.

Kryminalistyka została także wprowadzona do programu aplikacji, jednak faktyczna jej realizacja budzi istotne wątpliwości. W ramach aplikacji prokurator-

${ }^{30}$ Dane zebrano za pośrednictwem strony internetowej skierowanej do maturzystów podejmujących decyzję o wyborze studiów: https://www.otouczelnie.pl/artykul/1350/Prawo (dostęp: 10.06.2019).

31 Osiemnaście ośrodków to uczelnie wyższe publiczne, czternaście to uczelnie wyższe prywatne.

32 Nie wszystkie ośrodki udzielają na swoich stronach internetowych informacji o formie prowadzenia zajęć, dane w tej części nie są ostatecznie i pełne.

33 Nie zawsze można było dotrzeć do danych obrazujących liczbę godzin przeznaczoną na kryminalistykę. Niewiele uczelni proponuje wymiar godzinowy, który przekracza 60 godzin. Są także uczelnie, na których zaplanowano na zajęcia z kryminalistyki tylko od 5 do maksymalnie 20 godzin. 
skiej proponowanej w Krajowej Szkole Sądownictwa i Prokuratury zaplanowano przeprowadzenie dziewięćdziesięciu godzin z zakresu nauki kryminalistyki. Są to zajęcia realizowane w różnych formach, na przykład zajęcia $\mathrm{z}$ aktami, rozwiązywanie kazusów, zajęcia z biegłymi różnych specjalności kryminalistycznych, zajęcia w postaci seminariów i praktyk w laboratoriach policyjnych ${ }^{34}$. Natomiast aplikacja sędziowska w Krajowej Szkole Sądownictwa i Prokuratury oferuje zajęcia z elementów kryminalistyki połączonych z zagadnieniami z medycyny sądowej w łącznym wymiarze dziesięciu godzin. Należy zaznaczyć, że są to zajęcia uzupełniające ${ }^{35}$. W ramach szkolenia dotyczącego metodyki pracy adwokata w postępowaniu przygotowawczym przewidziany jest do realizacji temat odnoszący się do elementów kryminalistyki, w ramach którego omawiane są przykładowo: taktyka przesłuchania świadka, podejrzanego, oskarżonego, pokrzywdzonego, psychologiczne aspekty wiarygodności zeznań i wyjaśnień. Na omówienie wymienionych treści programowych przeznaczono cztery godziny ${ }^{36}$. Na aplikacji radcowskiej zajęcia z kryminalistyki nie zostały przewidziane, brakuje jakichkolwiek informacji o tym przedmiocie w programie nauczania ${ }^{37}$.

Konkluzja wynikająca z dokonanego rozpoznania jest jednoznaczna. System kształcenia przyszłych prawników w zakresie kryminalistyki jest daleki od doskonałości i nie napawa optymizmem na przyszłość, zwłaszcza w kontekście pomyłek sądowych, które — jak pokazują badania — coraz częściej pojawiają się w sądowej rzeczywistości. Sytuacja wymaga rozważenia i wypracowania prawdopodobnie nowych strategii, odnoszących się przede wszystkim do zwiększenia liczby godzin w zakresie dydaktyki przy jednoczesnym zwiększeniu rangi kryminalistyki na różnych etapach prawniczej edukacji.

Wracając do zasygnalizowanego na wstępie rozważań wątku pomyłek sądowych, należy nieustannie dociekać przyczyn wydawania błędnych wyroków. Analiza powinna dotyczyć poszczególnych spraw, a także uwzględniać sumarycznie pewne ,inwersje”, związane między innymi z poziomem wiedzy kryminalistycznej reprezentowanym przez prowadzących postępowania karne, które przyczyniają się do obecnego stanu rzeczy. Należy określić, co niezwłocznie musi zostać poprawione, aby łańcuch pomyłek sądowych nie był zbyt długi. W ostatecznej konkluzji można przywołać słowa francuskiego filozofa Michela de Montaigne, który przed laty doszedł do wniosku, że pomyłki wymiaru sprawiedliwości to „wyroki bardziej zbrodnicze niż same zbrodnie"38.

34 https://www.kssip.gov.pl/aplikacje/programy-aplikacji/aplikacja-prokuratorska (dostęp: 12.06.2019).

35 https://www.kssip.gov.pl/aplikacje/programy-aplikacji/aplikacja-sedziowska (dostęp:

12.06.2019).

$36 \mathrm{http}: / /$ www.adwokatura.pl/aplikacja-adwokacka/ (dostęp: 12.06.2019).

37 https://www.oirpwarszawa.pl/.../2019/.../2019-01-09-REGULAMIN-ODBYWANIA-A (dostęp: 10.07.2019).

38 D.H. Otto, W imieniu pomytki, Warszawa 2007, s. 382-383. 


\title{
JUDICIAL MISTAKES AND FORENSIC SCIENCE KNOWLEDGE
}

\author{
Summary
}

Scientific research proves that one of the causes of judicial mistakes is lack of forensic science knowledge amongst judicial authority. The aim of the paper is to show the state of forensic science education at Polish law universities and vocational education of prosecutors and judges.

Keywords: judicial mistakes, forensic science knowledge, wrongful conviction

\section{BIBLIOGRAFIA}

Bulsiewicz A., Proces o odszkodowanie za niestuszne skazanie lub oczywiście bezzasadny areszt tymczasowy, Toruń 1968.

Chojniak Ł., Wiśniewski Ł., Przyczyny niestusznych skazań w Polsce, Warszawa 2012.

Cioch P., Odpowiedzialność Skarbu Państwa z tytulu niestusznego skazania, Warszawa 2007.

Czajka W., Nowe postępowanie przygotowawcze w kontekście zapobiegania nieshusznym skazaniom, [w:] Niestuszne skazania - przyczyny i skutki, red. Ł. Chojniak, Warszawa 2017.

Gruza E., Goc M., Moszczyński J., Kryminalistyka, czyli rzecz o metodach śledczych, Warszawa 2008.

Helsińska Fundacja Praw Człowieka, Klinika Prawa „Niewinność”, Warszawa 2007.

Juchacz W., Okoliczności sprzyjające pomyłkom sądowym w zakresie ustaleń faktycznych, „Prokuratura i Prawo" 2004, nr 5.

Juchacz W., Pomytki sądowe w sprawach o zabójstwa. Studium karno-procesowe, Bydgoszcz 2016.

Kasprzak J., Btad w jednaj sprawie, czyli jeszcze raz o potrzebie znajomości kryminalistyki przez prawników, [w:] Kryminalistyka dla prawa, prawo dla kryminalistyki, red. V. Kwiatkowska-Wójcikiewicz, Toruń 2010.

Kołecki H., Zakres i sposób uprawiania kryminalistyki w Polsce, [w:] Księga pamiątkowa dedykowana Profesorowi Mirostawowi Owocowi, red. H. Kołecki, Poznań 2008.

Kulicki M., Kwiatkowska-Wójcikiewicz V., Stępka L., Kryminalistyka. Wybrane zagadnienia teorii i praktyki śledczo-sądowej, Torun 2009.

Kwiatkowska-Wójcikiewicz V., Kryminalistyka dla prawa, prawo dla kryminalistyki, Torun 2010.

Locard E., Dochodzenie przestępstw wedtug metod naukowych, Łódź 1937.

Mazur O., Niestuszne skazania w Polsce w opinii prokuratorów i policjantów, „Palestra” 2012, nr 3-4.

Otto D.H., W imieniu pomytki, Warszawa 2007.

Skorupka J., Pomyłki sadowe w orzecznictwie Sąu Najwyższego i sądów apelacyjnych, [w:] Niestuszne skazania - przyczyny i skutki, red. Ł. Chojniak, Warszawa 2017.

Sowa A., Przyczyny pomyłek sądowych, „Palestra” 2002, nr 1.

Waszczykowski J., Odszkodowanie za niestuszne skazanie i bezzasadne aresztowanie w polskim procesie karnym, Łódź 1964.

Widacki J., Dudzińska A., Pomyłki sądowe. Skazania osób niewinnych przez sądy w Polsce, „Palestra" 2007, nr 11-12. 